\title{
cmaJOPEN
}

\section{Wait-time reporting systems for elective surgery in Canada: a content analysis of provincial and territorial initiatives}

\author{
Romy E. Segall BSc, Julie L. Takata MA, David R. Urbach MD MSc
}

Abstract

Background: In Canada, a substantial barrier to the accessibility of surgical procedures is wait times. The objective of this study was to develop and describe an inventory of wait-time reporting systems for elective surgical procedures.

Methods: Between June and August 2019, we searched all Canadian provincial and territorial ministry of health websites to identify the wait-time reporting systems in place. We conducted content analysis and used a qualitative descriptive approach to compare the variables of interest across the provinces and territories.

Results: There were websites available for assessment in all 13 provinces and territories. Seven provinces have comprehensive, centralized wait-time reporting systems. The rest of the provinces have highly decentralized wait-time reporting, and the territories do not have wait-time reporting systems in place. There is substantial variation in the comprehensiveness, purpose, data sources and data collection methods among the wait-time reporting systems across the provinces and territories.

Interpretation: Wait-time reporting for elective surgery in Canada is diverse, and it varies in comprehensiveness across the provinces and territories. The present findings can help direct future investigations of Canadian reporting systems, which would provide useful information for policy-makers and those interested in reducing wait times in Canada.

imited access to health care services is a global problem, and the barriers to access differ across countries and regions. In Canada, wait times constitute a substantial barrier to the accessibility of surgical procedures. In the 2017 Commonwealth Fund Report, Canada was ranked tenth of 11 countries in terms of access to health services, largely because of long wait times for services such as elective surgery. ${ }^{1}$ Long wait times for elective surgery can cause anxiety and pain, worsen health status and increase recovery time after treatment. ${ }^{2}$ Public concern about wait times pressures governments and health authorities to act to improve timely access to health care services. ${ }^{2}$

Between the 2004 and 2005 Canadian first ministers' meetings on the future of health care, national benchmarks and reporting standards for 5 priority areas were developed. ${ }^{3}$ The Canadian Institute for Health Information was mandated to collect data on wait times for the 5 priority areas: sight restoration (cataract surgery), cardiac care (coronary artery bypass graft), hip (elective and fracture repair) and knee joint replacements, cancer surgery (breast, bladder, colorectal, lung and prostate) and diagnostic imaging tests. ${ }^{4}$ The priority areas remain unchanged. ${ }^{5}$

Waiting for elective surgery usually involves 2 types of waits; the first wait is the time between the date a patient receives a referral from a primary care physician and the date of their specialist consultation (labelled Wait 1), and the second is the time between the decision to proceed with surgery and the surgery itself (labelled Wait 2). ${ }^{6}$ The national reporting standards established in 2004 required that Wait 2 be reported for the 5 priority areas. Some provinces have gone beyond the national reporting standards and report wait times for more procedures. For example, Ontario created an online database that provides wait time information for a variety of surgical procedures, called the Wait Time Information System, ${ }^{7}$ in which wait time data are routinely collected from individual surgeons and compiled for public use. ${ }^{8}$

Although there has been some progress in recent years, Canadian wait times for elective surgery are still long. A qualitative content analysis of provincial and territorial waittime reporting systems would provide valuable insight into wait-time reporting systems across Canada. The objective of this study was to develop and describe an inventory of surgical wait-time reporting systems in each Canadian province and territory.

Competing interests: None declared.

This article has been peer reviewed.

Correspondence to: David Urbach, david.urbach@wchospital.ca

CMAJ Open 2020. DOI:10.9778/cmajo.20200033 


\section{Methods}

\section{Setting and design}

Using a qualitative descriptive approach, we conducted a search of all provincial and territorial ministry of health websites in Canada. Canada has 10 provinces and 3 territories, each with its own government; in turn, each government has a ministry of health. The websites of the provincial and territorial governments and the websites of their ministries of health constitute the general setting for this study. The present study focuses on variations in the collection and reporting of wait times for elective surgeries among the provinces and territories.

\section{Data sources}

We manually searched the websites of the ministry of health for each province and territory to identify the wait-time reporting systems in place. The search was conducted between June and August 2019. We first used the Google search engine to identify the URL for the website of each provincial and territorial ministry of health. Each of these websites was then searched using the search term "wait times." Press releases, government publications and web pages retrieved in the search as well as relevant menus and submenus accessed from these web pages were reviewed for information pertaining to wait-time information systems and websites reporting wait times.

The inclusion criteria were as follows: English-language websites or documents, and websites maintained by the provincial or territorial government and reporting on surgical wait times. The exclusion criteria were as follows: French-language websites or documents, and wait times for diagnostic imaging.

When information from government sources was insufficient to determine if the information was collected or available, we (R.E.S., J.L.T.) then searched PubMed. We used as search terms the names of relevant provincial or territorial wait-time reporting systems and the phrases "wait time" and "reporting" and "(province or territory)," or "wait times" and "surgery" and "(province/territory)," to determine whether more information about each system, relevant dates and the reporting process was available. Our search strategy is included in Appendix 1 (available at www.cmajopen.ca/ content/8/4/E844/suppl/DC1).

\section{Data collection}

All of the study authors designed the structured data collection form through team meetings at the beginning of the study. The form went through several iterations before we decided on the final version. Data abstraction was done according to this form. R.E.S. collected and categorized the data, which were verified and double-checked by J.L.T. Discrepancies were resolved by consensus among the research team (R.E.S., J.L.T., D.R.U.). The data were entered into and organized in a spreadsheet.

\section{Variables of interest}

For each province and territory, we gathered information about the wait-time reporting system and wait-time reporting website. We selected the variables of interest to align with the study's objective of describing the content, scope and processes of these systems. The variables are described below.

First, we were interested in whether any centralized waittime reporting system was in place. A centralized wait-time reporting system was defined for this study as a province- or territory-wide program that collected data for various elective surgical procedures into a single database. We were also interested in the scope of procedures for which wait-time data were collected (e.g., whether data were collected only for procedures in the 5 priority areas of sight restoration [cataract surgery], cardiac care [coronary artery bypass graft], hip [elective and fracture repair] and knee joint replacements, cancer surgery [breast, bladder, colorectal, lung and prostate] and diagnostic imaging tests, or for a broader variety of surgical procedures). In addition, we determined which wait time intervals were measured (Wait 1 or Wait 2 or both). ${ }^{6}$

Information was collected about whether a diagnostic prioritization system was used for determining target wait times and whether benchmarks were used. A diagnostic prioritization system was defined for this study as a method for determining acceptable target wait times for patients on the basis of the urgency or acuity of a patient's condition. A comprehensive diagnostic prioritization system was defined as a system that was embedded within a centralized wait-time reporting system that included 2 or more different surgical procedures. A benchmark was defined as a standard against which actual wait times were measured.

We gathered information about the data sources, data collection procedures, frequency of data collection, and use of data quality and error checks. We were also interested in the date the wait-time reporting systems were established.

Second, we reviewed the publicly available wait-time reporting websites of the provinces and territories. For waittime reporting websites, we collected information about the procedures for which wait times were reported; the time intervals reported (Wait 1 or Wait 2 or both); how information was reported, including statistical aggregation; the frequency of data updates on the website; the source of data; and when the website was established.

\section{Data analysis}

We used a qualitative descriptive approach and content analysis $^{9-11}$ to analyze the content of selected provincial and territorial ministry of health websites. A qualitative descriptive approach is appropriate when plain descriptions of phenomena are desired. ${ }^{11}$ We adapted our coding system to the data collected. ${ }^{9}$ The content found on the websites was coded by the defined variables and we compared the variables of interest across the provinces and territories to assess their commonalities and differences. We used Microsoft Excel to sort, code and analyze the data. The primary intent of the study was descriptive; we did not perform quantitative statistical analyses.

\section{Ethics approval}

Ethics approval was not required for this study as all data were publicly available. 


\section{Results}

There was a website for the health ministries of each province and territory (Appendix 1, Supplemental Table S1). Nine provinces had a website specifically reporting surgical wait times. Newfoundland Labrador and the 3 territories did not have surgical wait-time reporting websites (Appendix 1, Supplemental Table S2). A supplemental search of PubMed identified 647 articles. After reviewing the titles and abstracts, we retrieved 7 articles for a full-text review; none yielded relevant information for our study (Appendix 1, Supplemental Table S3).

\section{General characteristics of wait-time reporting systems}

Table 1 presents an overview of the wait-time reporting systems in the provinces and territories. Seven provinces had comprehensive, centralized wait-time reporting systems; the rest of the provinces had highly decentralized wait-time reporting and the territories did not have wait-time reporting systems in place (Figure 1). Provinces with centralized systems have created registries where data are entered into a unified database so that wait times can be monitored for many, if not all, surgical procedures (British Columbia, Alberta, Saskatchewan, Ontario, Quebec, Nova Scotia and New Brunswick). Although all provinces must report wait times for the priority areas, most provinces have gone beyond the nationally mandated reporting requirements for wait times for procedures in the 5 priority areas. BC, for instance, has created a Surgical Patient Registry that collects wait time data for all elective surgical procedures. ${ }^{12}$ In contrast, as an example of what is happening in other provinces and territories, Manitoba has separate registries for cardiac surgery (Cardiaccess), cataract surgery (Manitoba Cataract Surgery Waiting List Program) and joint replacement (Hip/Knee Replacement Registry) and reports wait times only for procedures in these priority areas. ${ }^{13}$

Wait 2 was the time interval most reported by the provinces and territories; Wait 1 was far less frequently reported. Ontario and Nova Scotia report Wait 1 consistently across the province. ${ }^{7,14}$ Alberta's Referral Directory allows for the submission of Wait 1 data, but only some specialists report to it. British Columbia also seems to be heading in the direction of reporting Wait 1 data. ${ }^{15}$

Comprehensive diagnostic prioritization systems were part of some registries and databases. Alberta Coding Access Targets

Table 1: Overview of the wait-time reporting systems for elective surgery in Canadian provinces and territories

\begin{tabular}{|c|c|c|c|c|c|c|c|c|c|c|c|}
\hline Characteristic & $\mathrm{BC}$ & $A B$ & SK & $\mathrm{MB}$ & ON & QC & NL & NS & NB & $\mathrm{PE}$ & TRS \\
\hline MOH budget, \$ & $\begin{array}{c}20.8 \\
\text { billion }\end{array}$ & $\begin{array}{c}20.6 \\
\text { billion }\end{array}$ & $\begin{array}{c}5.89 \\
\text { billion }\end{array}$ & $\begin{array}{c}6.65 \\
\text { billion }\end{array}$ & $\begin{array}{c}63.5 \\
\text { billion }\end{array}$ & $\begin{array}{c}39 \\
\text { billion }\end{array}$ & $\begin{array}{l}3.2 \\
\text { billion }\end{array}$ & $\begin{array}{c}4.6 \\
\text { billion }\end{array}$ & $\begin{array}{l}2.8 \\
\text { billion }\end{array}$ & $\begin{array}{l}750 \\
\text { million }\end{array}$ & $\begin{array}{l}1.36 \\
\text { billion†† }\end{array}$ \\
\hline $\begin{array}{l}\text { Centralized wait-time } \\
\text { reporting system exists* }\end{array}$ & $\checkmark$ & $\checkmark$ & $\checkmark$ & & $\checkmark$ & $\checkmark$ & & $\checkmark$ & $\checkmark$ & & \\
\hline $\begin{array}{l}\text { Wait times reported for more } \\
\text { than procedures included in } \\
\text { the } 5 \text { priority areas } \dagger\end{array}$ & $\checkmark$ & $\checkmark$ & $\checkmark$ & & $\checkmark$ & $\checkmark$ & & $\checkmark$ & $\checkmark$ & & \\
\hline $\begin{array}{l}\text { Wait times reported for } \\
\text { procedures in the } 5 \text { priority } \\
\text { areas }\end{array}$ & & & & $\checkmark$ & & & $\checkmark$ & & & $\checkmark$ & \\
\hline Wait $1 \neq$ measured & $\checkmark$ & $\checkmark \ddagger \ddagger$ & & & $\checkmark$ & & & $\checkmark$ & NR & & \\
\hline Wait $2 \S$ measured & $\checkmark$ & $\checkmark$ & $\checkmark$ & $\checkmark$ & $\checkmark$ & $\checkmark$ & $\checkmark \S \S$ & $\checkmark$ & $\checkmark$ & $\checkmark$ & \\
\hline $\begin{array}{l}\text { Comprehensive diagnostic } \\
\text { prioritization system exists }\end{array}$ & $\checkmark$ & $\checkmark$ & $\checkmark$ & & $\checkmark$ & $\checkmark$ & & $\checkmark$ & $\checkmark$ & & \\
\hline Benchmarks established** & $\checkmark$ & $\checkmark$ & $\checkmark$ & & $\checkmark$ & $\checkmark$ & & $\checkmark$ & $\checkmark$ & & \\
\hline $\begin{array}{l}\text { Data quality and error } \\
\text { checks }\end{array}$ & $\checkmark$ & $\checkmark$ & NR & NR & $\checkmark$ & NR & NR & $\checkmark$ & $\checkmark$ & NR & \\
\hline \multicolumn{12}{|c|}{ 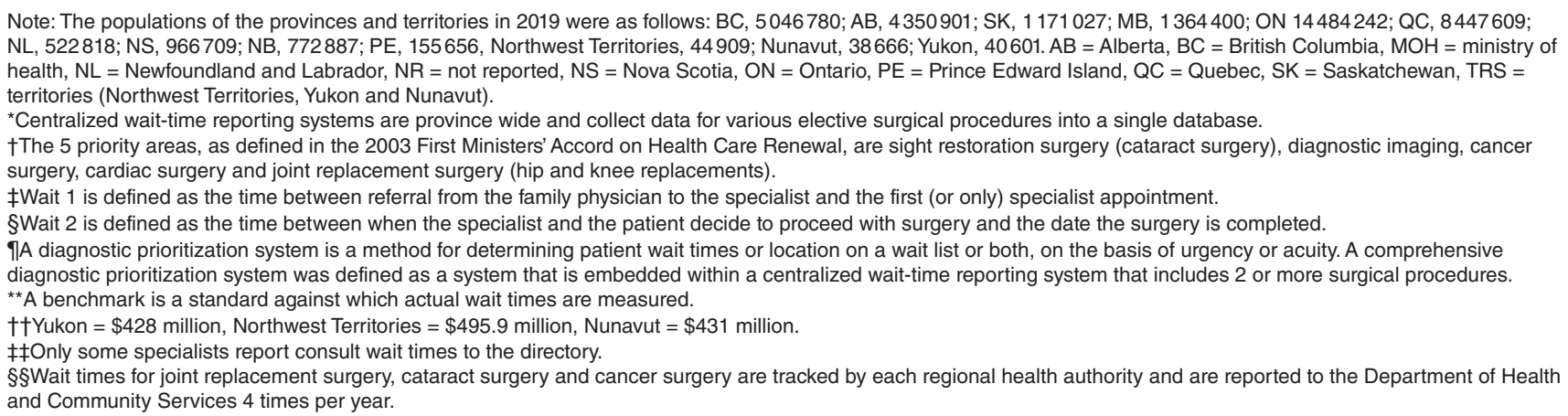 } \\
\hline
\end{tabular}




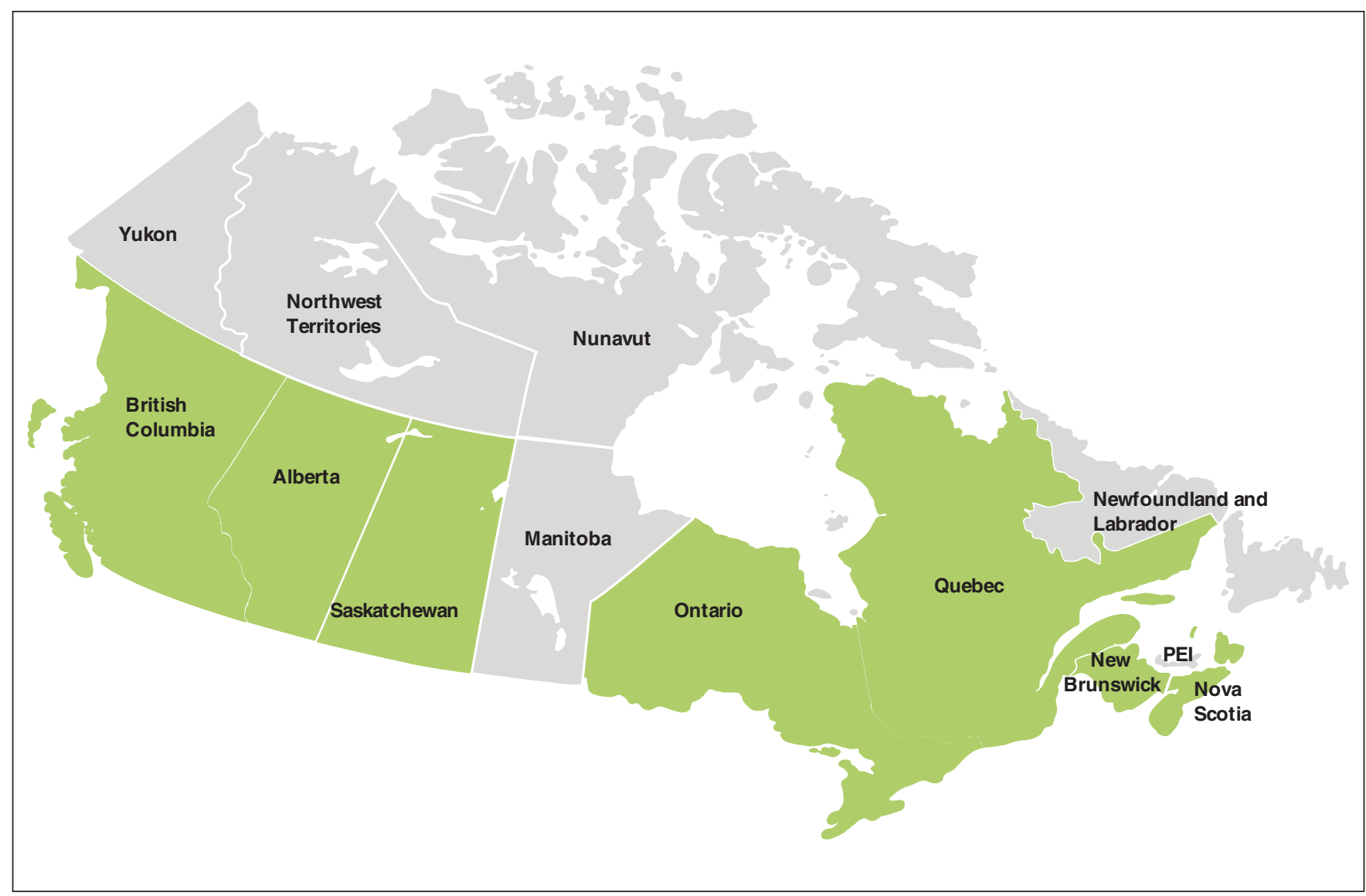

Figure 1: Map of Canada. Note: Provinces in green have centralized wait-time reporting systems in place. PEI = Prince Edward Island. @ Copyright PresentationGO.com. Reproduced with permission.

for Surgery is a prioritization system for all elective surgical procedures. Patients are assigned a code on the basis of their diagnosis. The patient's position on a waiting list is determined on the basis of their diagnosis, their level of acuity and the number of days until the target wait time is reached. ${ }^{16}$ Some wait-time data were reported with reference to a benchmark. For example, in Manitoba the wait-time website reports wait-time statistics as "percent of surgeries done within benchmark." ${ }^{17}$ Some of the provinces provided information about their data quality and error checking processes.

\section{Data sources and methods of data collection}

Table 2 presents information about the collection of waittime data in provinces with centralized wait-time reporting systems for elective surgery. In BC, the Provincial Health Services Authority collects and manages information entered into the online Surgical Patient Registry by operating room booking staff. ${ }^{12}$ Quebec has designated staff members at each health care institution who enter the data directly into the database. ${ }^{18}$ Most provinces report wait times in near real time and these reporting systems are constantly updated.

Provincial and territorial wait-time reporting websites All provinces except Newfoundland and Labrador have separate wait-time reporting websites (Table 3; links provided in
Appendix 1, Supplemental Table S2). The territories have no websites dedicated to wait-time reporting.

Wait 2 was reported on all provincial wait-time websites. Wait 1 was reported only in Ontario and Nova Scotia.

Provincial wait-time reporting websites also differ in how the data are presented (Table 4). For all provinces, data are presented by procedure, location, and hospital or institution. Some websites have user-directed search features. For example, the Alberta website permits users to search for wait-time data by procedure, surgeon, hospital or institution, location, or time period. Some provinces report wait times by time period (e.g., monthly) and surgeon, as well. Most provinces publish percentile statistics (50th and 90th) and average wait times.

Most websites were updated monthly (Alberta, Ontario, Quebec, and Newfoundland and Labrador) or bimonthly (BC). New Brunswick and Nova Scotia update their websites quarterly. Saskatchewan's website is updated continuously. ${ }^{18}$

\section{Interpretation}

All provinces except Newfoundland and Labrador have websites to publicly report wait-time information for elective surgeries. Seven provinces have comprehensive, centralized waittime reporting systems. Many provinces have gone beyond the 
Table 2: Data source and method of collection for provincial and territorial wait-time reporting systems for elective surgery

\begin{tabular}{|c|c|c|c|c|c|c|c|c|c|c|c|}
\hline Variable & $B C$ & $A B$ & SK & $M B^{*}$ & ON & QC & $\mathrm{NL}^{*}$ & NS & NB & $P E^{*}$ & TRS* \\
\hline $\begin{array}{l}\text { Entity } \\
\text { tasked } \\
\text { with } \\
\text { reporting } \\
\text { wait-time } \\
\text { data }\end{array}$ & $\begin{array}{l}\text { Health } \\
\text { authorities, } \\
\text { operating } \\
\text { room } \\
\text { booking } \\
\text { staff }\end{array}$ & $\begin{array}{c}\text { Operating } \\
\text { Room } \\
\text { Information } \\
\text { System (ORIS) }\end{array}$ & NR & & $\begin{array}{l}\text { Hospitals } \\
\text { and clinical } \\
\text { offices, } \\
\text { Cardiac } \\
\text { Care } \\
\text { Network }\end{array}$ & $\begin{array}{l}\text { Assigned staff in } \\
\text { every health care } \\
\text { institution }\end{array}$ & & $\begin{array}{l}\text { District } \\
\text { health } \\
\text { authorities }\end{array}$ & $\begin{array}{l}\text { Hospital } \\
\text { staff }\end{array}$ & & \\
\hline $\begin{array}{l}\text { Entity } \\
\text { tasked } \\
\text { with } \\
\text { collecting } \\
\text { wait-time } \\
\text { data }\end{array}$ & $\begin{array}{l}\text { Provincial } \\
\text { Health } \\
\text { Services } \\
\text { Authority } \\
\text { (PHSA) }\end{array}$ & $\begin{array}{c}\text { Alberta Coding } \\
\text { Access Targets } \\
\text { for Surgery } \\
\text { (ACATS) }\end{array}$ & $\begin{array}{l}\text { Surgical } \\
\text { Patient } \\
\text { Registry }\end{array}$ & & $\begin{array}{l}\text { Wait Time } \\
\text { Information } \\
\text { System } \\
\text { (WTIS) }\end{array}$ & $\begin{array}{l}\text { Information System } \\
\text { for Managing } \\
\text { Access } \\
\text { Mechanisms to } \\
\text { Specialized } \\
\text { Services (SIMASS) }\end{array}$ & & $\begin{array}{l}\text { Patient } \\
\text { Access } \\
\text { Registry } \\
\text { Nova } \\
\text { Scotia } \\
\text { (PAR NS) }\end{array}$ & $\begin{array}{l}\text { Surgical } \\
\text { Patient } \\
\text { Registry }\end{array}$ & & \\
\hline $\begin{array}{l}\text { Schedule } \\
\text { for } \\
\text { updating } \\
\text { wait-time } \\
\text { data }\end{array}$ & Daily & $\begin{array}{l}\text { Varies by } \\
\text { report }\end{array}$ & Daily & & $\begin{array}{l}\text { Near real } \\
\text { time }\end{array}$ & Real time & & NR & $\begin{array}{l}\text { Real } \\
\text { time }\end{array}$ & & \\
\hline
\end{tabular}

Table 3: General characteristics of websites reporting wait times for elective surgery in Canadian provinces and territories

\begin{tabular}{|c|c|c|c|c|c|c|c|c|c|c|c|}
\hline Characteristic & $\mathrm{BC}$ & $A B$ & SK & MB & ON & QC & NL & NS & NB & PE & TRS \\
\hline Wait-time reporting website exists* & $\checkmark$ & $\checkmark$ & $\checkmark$ & $\checkmark$ & $\checkmark$ & $\checkmark$ & 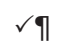 & $\checkmark$ & $\checkmark$ & $\checkmark$ & \\
\hline $\begin{array}{l}\text { Wait times reported for more than procedures } \\
\text { included in the } 5 \text { priority areas } t\end{array}$ & $\checkmark$ & $\checkmark$ & $\checkmark$ & & $\checkmark$ & $\checkmark$ & & $\checkmark$ & $\checkmark$ & & \\
\hline $\begin{array}{l}\text { Wait times reported for procedures in the } 5 \text { priority } \\
\text { areas }\end{array}$ & & & & $\checkmark$ & & & $\checkmark$ & & & $\checkmark$ & \\
\hline Wait $1 \ddagger$ reported & & & $\checkmark^{* *}$ & & $\checkmark$ & & & $\checkmark$ & & & \\
\hline Wait $2 \S$ reported & $\checkmark$ & $\checkmark$ & $\checkmark$ & $\checkmark$ & $\checkmark$ & $\checkmark$ & $\checkmark$ & $\checkmark$ & $\checkmark$ & $\checkmark$ & \\
\hline \multicolumn{12}{|c|}{$\begin{array}{l}\text { Note: } \mathrm{AB}=\text { Alberta, } \mathrm{BC}=\text { British Columbia, } \mathrm{MB}=\text { Manitoba, } \mathrm{NB}=\text { New Brunswick, } \mathrm{NL}=\text { Newfoundland and Labrador, } \mathrm{NS}=\text { Nova Scotia, } \mathrm{ON}=\mathrm{Ontario}, \mathrm{PE}=\mathrm{Prince} \text { Edward } \\
\text { Island, } \mathrm{QC}=\text { Quebec, } \mathrm{SK}=\text { Saskatchewan, TRS = territories (Northwest Territories, Yukon and Nunavut). } \\
{ }^{*} \text { The websites may be reporting data from a centralized wait-time reporting system or a decentralized reporting process. }\end{array}$} \\
\hline \multicolumn{12}{|c|}{$\begin{array}{l}\text { †The } 5 \text { priority areas, as defined in the } 2003 \text { First Ministers' Accord on Health Care Renewal, are sight restoration surgery (cataract surgery), diagnostic imaging, cancer } \\
\text { surgery, cardiac surgery and joint replacement surgery (hip and knee replacements). }\end{array}$} \\
\hline \multicolumn{12}{|c|}{ ¥Wait 1 is defined as the time between referral from the family physician to the specialist and the first (or only) specialist appointment. } \\
\hline \multicolumn{12}{|c|}{$\begin{array}{l}\text { §Wait } 2 \text { is defined as the time between when the specialist and the patient decide to proceed with surgery and the date the surgery is completed. } \\
\text { १There is no single website devoted to wait-time reporting. However, reports are published on the Western Health website and the Health and Community Services website } \\
{ }^{*} \text { The website indicates that Wait } 1 \text { reporting is under development. }\end{array}$} \\
\hline
\end{tabular}

national reporting standards in terms of procedures reported, and all provinces with reporting systems have standardized diagnostic prioritization systems in place. The territories do not report or publish wait-time data for elective surgeries.

Although Wait 1 times represent an important part of the wait for surgery, these times are not consistently reported across Canada. In general, Wait 1 data are more difficult and expensive to collect, because they require obtaining information directly from referring primary care physicians as well as specialists. While Wait 2 times are generally well reported, the definition of Wait 2 is not consistent across Canada. ${ }^{19}$ For example, this wait time interval may begin only on the date the hospital has received operating room booking information, which does not account for other system delays in the data-entry process. ${ }^{2}$ There is also unaccounted time between Wait 1 and Wait 2, because Wait 1 ends at the first specialist appointment and Wait 2 starts only at the decision to treat. This highlights an opportunity for consistency across the provinces in terms of wait-time definitions and reporting. Creating a national reporting standard that goes beyond the 5 priority areas may encourage reporting and, ultimately, increase the accessibility of health care services.

Many European countries have nationwide reporting systems and databases. ${ }^{20}$ Fifteen of 23 member countries of the Organisation for Economic Co-operation and Development that have a GDP per capita that is similar to that of Canada and whose residents' health status is similar to that of Canadians, monitor and publish national wait-time statistics. ${ }^{21}$ Hospitals in the Netherlands are required to report data on waiting times on their websites each month. ${ }^{22}$ Elective surgery is the most common health service for which wait times 
are measured, with countries such as Sweden, England, Spain and the Netherlands going further and providing wait times by specialty and for specific operations; most countries begin measuring wait times from the date of the decision to treat (Wait 2). ${ }^{21}$ The procedures for which wait times are most commonly measured and reported internationally are hip and knee replacement, cataract surgery, hysterectomy, prostatectomy, cholecystectomy, hernia repair, coronary artery bypass grafting and percutaneous transluminal coronary angioplasty. ${ }^{22}$

Canada's size and the jurisdictional nature of health care, where each province runs its own health ministry, limits the feasibility of nationwide, centralized databases. Development of provincial and territorial reporting systems and registries that adopt national standards would increase comparability across Canada and result in more consistent wait-time data.

It is unclear who is using reported wait-time information and for what purpose. Understanding the extent of use of wait-time data and ways to increase awareness of these data among patients and health care providers is an important future research direction. Further research is needed to understand how physicians, the public and other stakeholders use this information when making health care decisions. If data are not extensively used to help reduce wait times, other strategies, such as central referral systems and single-entry models, would be helpful. The present findings can help direct future investigation of Canadian reporting systems, which would provide useful information for policy-makers and those interested in reducing wait times in Canada.

\begin{tabular}{|c|c|c|c|c|c|}
\hline Characteristic & $\mathrm{BC}$ & $A B$ & SK & MB & ON \\
\hline $\begin{array}{l}\text { Data presented } \\
\text { by procedure }\end{array}$ & $\checkmark$ & $\checkmark$ & $\checkmark$ & $\checkmark$ & $\checkmark$ \\
\hline $\begin{array}{l}\text { Data presented } \\
\text { by surgeon }\end{array}$ & $\checkmark$ & $\checkmark$ & $\checkmark$ & & \\
\hline $\begin{array}{l}\text { Data presented } \\
\text { by hospital or } \\
\text { institution }\end{array}$ & $\checkmark$ & $\checkmark$ & & $\checkmark$ & $\checkmark$ \\
\hline $\begin{array}{l}\text { Data presented } \\
\text { by location (e.g., } \\
\text { health authority, } \\
\text { zone, community) }\end{array}$ & $\checkmark$ & $\checkmark$ & $\checkmark$ & $\checkmark$ & $\checkmark$ \\
\hline $\begin{array}{l}\text { Data presented } \\
\text { by time period } \\
\text { (e.g., month, } \\
\text { year) }\end{array}$ & & $\checkmark$ & & $\checkmark$ & \\
\hline $\begin{array}{l}\text { Information } \\
\text { included }\end{array}$ & $\begin{array}{l}\text { - No. of cases waiting } \\
\text { - No. of cases } \\
\text { completed } \\
\text { - 50th (median) and } \\
\text { 90th percentile wait } \\
\text { times }\end{array}$ & $\begin{array}{l}\text { - 25th, 50th, 75th and } \\
\text { 90th percentile wait } \\
\text { times } \\
\text { - Average (mean) wait } \\
\text { time } \\
\text { - No. of procedures } \\
\text { completed }\end{array}$ & $\begin{array}{l}\text { - No. of nonemergent } \\
\text { cases completed } \\
\text { - Time frame within } \\
\text { which } 50 \% \text { and } 90 \% \text { of } \\
\text { patients received } \\
\text { surgery (wk) } \\
\text { - Cases waiting } \\
\text { - Percentage of patients } \\
\text { waiting > } 3 \text { months } \\
\text { - Specialist will or will } \\
\text { not see patient using } \\
\text { video conferencing }\end{array}$ & $\begin{array}{l}\text { - No. of surgeries } \\
\text { performed/month } \\
\text { - Median wait times by } \\
\text { most recent } 2 \text { fiscal } \\
\text { years to date }\end{array}$ & $\begin{array}{l}\text { - Percentage of } \\
\text { patients seen within } \\
\text { target time (all } \\
\text { patients combined) } \\
\text { - For each priority level: } \\
\text { patients who should } \\
\text { be seen within a } \\
\text { target time of } X \text { days } \\
\text { waited on average X } \\
\text { days, percentage of } \\
\text { patients seen within } \\
\text { target time } \\
\text { - Can compare average } \\
\text { days waited across } \\
\text { various hospitals }\end{array}$ \\
\hline Data source & $\begin{array}{l}\text { - Surgical Patient } \\
\text { Registry } \\
\text { - Data not recorded by } \\
\text { the Surgical Patient } \\
\text { Registry are sent to } \\
\text { the } \mathrm{MOH} \text { by other } \\
\text { organizations }\end{array}$ & $\begin{array}{l}\text { - MOH receives data } \\
\text { from hospitals and } \\
\text { diagnostic clinics } \\
\text { - These institutions } \\
\text { gather information } \\
\text { from physicians and } \\
\text { specialists }\end{array}$ & $\begin{array}{l}\text { - Surgical Patient } \\
\text { Registry with the } \\
\text { exception of hip } \\
\text { fracture repair (data } \\
\text { come from CIHI) }\end{array}$ & $\begin{array}{l}\text { - Hospitals and other } \\
\text { facilities gather } \\
\text { wait-time data from } \\
\text { physician and } \\
\text { operating room } \\
\text { booking systems } \\
\text { - RHAs check the data } \\
\text { and send it to } \\
\text { Manitoba Health, } \\
\text { Seniors and Active } \\
\text { Living's Health } \\
\text { System Innovation } \\
\text { Branch }\end{array}$ & $\begin{array}{l}\text { - Wait Time Information } \\
\text { System (WTIS) }\end{array}$ \\
\hline Update frequency & Bimonthly & Monthly & Real time & NR & Monthly \\
\hline
\end{tabular}




\begin{tabular}{|c|c|c|c|c|c|c|}
\hline Characteristic & QC & NL & NS & NB & PE & TRS \\
\hline $\begin{array}{l}\text { Data } \\
\text { presented } \\
\text { by procedure }\end{array}$ & $\checkmark$ & $\checkmark *$ & $\checkmark$ & $\checkmark$ & $\checkmark$ & \\
\hline $\begin{array}{l}\text { Data } \\
\text { presented } \\
\text { by surgeon }\end{array}$ & & & $\checkmark$ & & & \\
\hline $\begin{array}{l}\text { Data } \\
\text { presented } \\
\text { by hospital } \\
\text { or institution }\end{array}$ & $\checkmark$ & $\checkmark \dagger$ & $\checkmark$ & $\checkmark$ & & \\
\hline $\begin{array}{l}\text { Data } \\
\text { presented } \\
\text { by location } \\
\text { (e.g., health } \\
\text { authority, } \\
\text { zone, } \\
\text { community) }\end{array}$ & $\checkmark$ & $\checkmark \ddagger$ & $\checkmark$ & & & \\
\hline $\begin{array}{l}\text { Data } \\
\text { presented } \\
\text { by time } \\
\text { period } \\
\text { (e.g., month, } \\
\text { year) }\end{array}$ & & $\checkmark \S$ & $\checkmark$ & & & \\
\hline $\begin{array}{l}\text { Information } \\
\text { included }\end{array}$ & $\begin{array}{l}\text { For patients operated } \\
\text { on: no. of patients, } \\
\text { percentage operated } \\
\text { on within } 3 \text { and } 6 \text { or } \\
\text { more months, and } \\
\text { average waiting time } \\
\text { - For patients waiting: no. } \\
\text { of patients waiting, no. } \\
\text { of patients waiting } 6 \\
\text { months or more }\end{array}$ & $\begin{array}{l}\text { WH website } \\
\text { - Median wait time } \\
\text { - Percentage of patients } \\
\text { for whom benchmark } \\
\text { was met } \\
\text { - Total no. of procedures } \\
\text { performed } \\
\text { HCS website } \\
\text { - No. of procedures } \\
\text { completed } \\
\text { - Time frame within which } \\
50 \% \text { and } 90 \% \text { of } \\
\text { procedures were } \\
\text { completed } \\
\text { - Percentage of procedures } \\
\text { performed within } \\
\text { benchmark }\end{array}$ & $\begin{array}{l}\text { - Maximum time } 90 \% \\
\text { and } 50 \% \text { of patients } \\
\text { waited } \\
\text { - Shortest wait time } \\
\text { - Wait-time trends }\end{array}$ & $\begin{array}{l}\text { - Time frame within } \\
\text { which } 50 \% \text { and } 90 \% \\
\text { of procedures were } \\
\text { completed } \\
\text { - Trend information } \\
\text { - No. of procedures } \\
\text { completed }\end{array}$ & $\begin{array}{l}\text { Time frame } \\
\text { within which } \\
90 \% \text { of } \\
\text { patients } \\
\text { were treated } \\
\text { (d) }\end{array}$ & \\
\hline Data source & $\begin{array}{l}\text { Information System for } \\
\text { Managing Access } \\
\text { Mechanisms to } \\
\text { Specialized Services } \\
\text { (SIMASS) }\end{array}$ & $\begin{array}{l}\text { WH website } \\
\text { - Hospitals and other } \\
\text { facilities get data from } \\
\text { physicians and } \\
\text { operating rooms or } \\
\text { booking systems } \\
\text { - Data are verified by each } \\
\text { RHA and submitted to } \\
\text { the Department of } \\
\text { Health and Community } \\
\text { Services } \\
\text { HCS website } \\
\text { - RHAs report wait-time } \\
\text { data to the Department } \\
\text { of Health and Community } \\
\text { Services }\end{array}$ & $\begin{array}{l}\text { Patient Access } \\
\text { Registry Nova Scotia } \\
\text { (PAR NS) }\end{array}$ & $\begin{array}{l}\text { Provincial Surgical } \\
\text { Access Registry }\end{array}$ & NR & \\
\hline $\begin{array}{l}\text { Update } \\
\text { frequency }\end{array}$ & Monthly & $\begin{array}{l}\text { Monthly or quarterly or } \\
\text { both }\end{array}$ & Quarterly & Quarterly & NR & \\
\hline \multicolumn{7}{|c|}{$\begin{array}{l}\text { Note: } \mathrm{AB}=\text { Alberta, } \mathrm{BC}=\text { British Columbia, } \mathrm{CIHI}=\text { Canadian Institute for Health Information, } \mathrm{HCS}=\text { Health and Community Services, } \mathrm{MB}=\mathrm{Manitoba}, \mathrm{MOH}=\text { ministry of } \\
\text { health, NB = New Brunswick, NL = Newfoundland and Labrador, NR = not reported, NS = Nova Scotia, ON = Ontario, } \mathrm{PE}=\text { Prince Edward Island, QC = Quebec, RHA = } \\
\text { regional health authority, } \mathrm{SK}=\text { Saskatchewan, TRS = territories (i.e., Northwest Territories, Yukon \& Nunavut), WH = Western Health. } \\
\text { "WH and HCS websites. } \\
\text { tWH website only. } \\
\text { fHCS website only. } \\
\text { §Yearly reports are posted on the HCS website. }\end{array}$} \\
\hline
\end{tabular}




\section{Limitations}

Our study was limited to the English-language content contained in provincial and territorial government websites, which may have led to some omissions as content may have differed on the French sites (all of the ministry of health websites offered the option to view the site in French). Data abstraction was conducted by 1 person, and our PubMed search did not include any National Library of Medicine medical subject headings $(\mathrm{MeSH})$ terms, which may have resulted in missed citations or data. We did not conduct interviews with provincial or territorial representatives, although we did contact individual ministries for help in locating missing documents referenced on the sites. We limited our study to a description of reporting websites; we did not analyze whether provincial and territorial wait times were too long, or whether problems in access to care are likely to cause adverse health consequences.

\section{Conclusion}

Wait-time reporting for elective surgery in Canada is diverse and varies in comprehensiveness across jurisdictions. This study shows the variation in reporting between jurisdictions even within a country with "national" reporting standards. The provinces and territories should adopt consistent reporting patterns and make their websites easy to use and understand for patients and primary care providers.

\section{References}

1. Schneider EC, Sarnak DO, Squires D, et al. Mirror, mirror 2017: international comparison reflects flaws and opportunities for better U.S. health care. New York: The Commonwealth Fund; 2017.

2. Barua B, Jacques D, Collyer A. Waiting your turn: wait times for bealth care in Canada, 2018 report. Vancouver: Fraser Institute; 2018. Available: www. fraserinstitute.org/sites/default/files/waiting-your-turn-2018.pdf (accessed 2019 July 29).

3. A 10-year plan to strengthen health care. Ottawa: Health Canada; 2004. Available: www.canada.ca/en/health-canada/services/health-care-system/health-care-system -delivery/federal-provincial-territorial-collaboration/first-ministers-meeting-year -plan-2004/10-year-plan-strengthen-health-care.html (accessed 2019 Sept. 24).

4. Wait times for priority procedures in Canada. Ottawa: Canadian Institute for Health Information; 2020. Available: www.cihi.ca/en/wait-times-for-priority -procedures-in-canada (accessed 2019 Sept. 24).

5. Wait time information in priority areas: definitions. Ottawa: Canadian Institute for Health Information; 2018. Available: www.cihi.ca/sites/default/ files/document/wt2018-info-on-priority-areas-definitions-en.pptx (accessed 2020 May 21).

6. Wait times for surgeries and procedures. Toronto: Health Quality Ontario. Available: www.hqontario.ca/System-Performance/Wait-Times-for-Surgeries -and-Procedures (accessed 2020 May 14).

7. Irish J. The Ontario wait times story: improving access and improving quality of care. Ottawa: Canadian Foundation for Health Care Improvement; 2013.

8. Ontario wait times: about wait times data. Toronto: Ministry of Health and Long-term Care; modified 2015 Nov. 2. Available: www.health.gov.on.ca/en/ pro/programs/waittimes/surgery/data.aspx (accessed 2019 July 29).
9. Neergaard MA, Olesen F, Andersen RS, et al. Qualitative description - the poor cousin of health research? BMC Med Res Methodol 2009;9:52.

10. Petch T. Content analysis of selected health information websites: final report. Burnaby (BC): Simon Fraser University; 2004.

11. Sandelowski M. Whatever happened to qualitative description? Res Nurs Health 2000;23:334-40.

12. BC Surgical Patient Registry. Vancouver: Provincial Health Services Authority. Available: www.phsa.ca/our-services/programs-services/bc-surgical-patient -registry (accessed 2019 July 29)

13. De Coster C, Chateau D, Dahl M, et al. Waiting times for surgery, Manitoba: 1999/2000 to 2003/04. Winnipeg: Manitoba Centre for Health Policy; 2007. Available: http://mchp-appserv.cpe.umanitoba.ca/reference/swt_3web.pdf (accessed 2019 July 29).

14. Surgical waitlist and operating room utilization. Halifax: Office of the Auditor General Nova Scotia; 2014. Available: https://oag-ns.ca/sites/default/files/ publications/2014\%20-\%20Dec\%20-Ch04\%20-\%20Surgical\%20Waitlist $\% 20$ and \% 20Operating\%20Room\%20Utilization.pdf (accessed 2019 July 29).

15. Wait time data collection. Victoria: British Columbia Ministry of Health www2.gov.bc.ca/gov/content/health/accessing-health-care/surgical-wait-times/ understanding-wait-times/wait-time-data-collection (accessed 2019 July 29).

16. Adult coding access targets for surgery: aCATS report guide — Edmonton Zone: 7uly 26 2016. Alberta Health Services; 2016. Available: https://albertahealthservices.ca/ assets/about/scn/ahs-scn-surg-acats-edmonton-reports-manual.pdf (accessed 2019 July 29).

17. Health services wait time information. Winnipeg: Government of Manitoba. Available: www.gov.mb.ca/health/waittime/index.html (accessed 2019 July 29).

18. Bernier J, MacLellan K, Clow B. Waiting for care in Canada: a report on the state of wait list management for hip and knee replacements from provincial and territorial government websites. Halifax: Dalhousie University; 2010. Available: https://cdn.dal.ca/content/dam/dalhousie/pdf/diff/ace-women -health/live/ACEWH_waiting_for_care_full_report.pdf (accessed 2019 July 29).

19. Frequently asked questions: general information wait times. Wait Time Alliance; 2014. Available: www.waittimealliance.ca/for-professionals/faqs/ (accessed 2019 July 29).

20. Swedish waiting times for health care in an international perspective. Stockholm (Sweden): Sveriges Kommuner och Landsting; 2011. Available: https:// webbutik.skl.se/bilder/artiklar/pdf/7164-735-1.pdf (accessed 2019 July 29).

21. Viberg N, Forsberg BC, Borowitz M, et al. International comparisons of waiting times in health care - limitations and prospects. Health Policy 2013; 112:53-61.

22. Siciliani L, Moran V, Borowitz M. Measuring and comparing health care waiting times in OECD countries. Health Policy 2014;118:292-303.

Affiliations: Department of Surgery (Segall, Takata, Urbach), Women's College Hospital; Department of Surgery (Urbach), University of Toronto, Toronto, Ont.

Contributors: All authors were responsible for the conception and design of the study. Romy Segall collected the data. All authors were involved in data analysis and interpretation. Romy Segall drafted the manuscript and all authors revised it for important intellectual content. All authors approved the final version to be published and agreed to be accountable for the work.

Data sharing: The data that support the findings of this study are available in the public domain from the websites listed in Appendix 1 (Supplemental Tables S1 and S2) of this article. Clarification or assistance can be obtained by contacting the corresponding author.

Supplemental information: For reviewer comments and the original submission of this manuscript, please see www.cmajopen.ca/content/8/4/ E844/suppl/DC1 